\title{
Thermal, Morphological and Cytotoxicity Characterization of Hardwood Lignins Isolated by In-Situ Sodium Hydroxide-Sodium Bisulfate Method
}

\author{
Ahmed Geies', Mohamed Abdelazim²*, Ahmed Mahmoud Sayed1', Sara Ibrahim² \\ ${ }^{1}$ Chemistry Department, Faculty of science, Assiut University, Assiut, Egypt \\ ${ }^{2}$ Chemical and Biotechnological Laboratories, Sugar Industry Technology Research Institute, Assiut University, Assiut, Egypt \\ Email: *maboulela@icloud.com
}

How to cite this paper: Geies, A., Abdelazim, M., Sayed, A.M. and Ibrahim, S. (2020) Thermal, Morphological and Cytotoxicity Characterization of Hardwood Lignins Isolated by In-Situ Sodium Hydroxide-Sodium Bisulfate Method. Natural Resources, 11, 427-438.

https://doi.org/10.4236/nr.2020.1110025

Received: August 29, 2020

Accepted: October 10, 2020

Published: October 13, 2020

Copyright $\odot 2020$ by author(s) and Scientific Research Publishing Inc. This work is licensed under the Creative Commons Attribution International License (CC BY 4.0).

http://creativecommons.org/licenses/by/4.0/

(c) (i) Open Access

\begin{abstract}
In the present work, lignin is isolated from three different agro-industrial waste, sweet sorghum, rice straw and sugarcane bagasse using in-situ sodium hydroxide-sodium bisulfate methodology. Characterization was performed using fourier transform infrared analysis (FTIR), scan electron microscopy (SEM), thermo gravimetric analysis (TGA). The SEM micrographs showed sponge-like structure except for sugarcane bagasse lignin reveals rock-like structure. The FTIR indicates the presence of hydroxyl, carbonyl and methoxyl groups in the lignin structure. TGA thermograms were relatively same and sugarcane bagasse lignin was found the most thermally stable up to $201^{\circ} \mathrm{C}$ as compared to both of soda and kraft sugarcane bagasse lignin and its maximal temperature degradation rate $\mathrm{DTG}_{\max }$ was found at $494^{\circ} \mathrm{C}$ while $450^{\circ} \mathrm{C}, 464^{\circ} \mathrm{C}$ in addition to thermal stabilities up to $173^{\circ} \mathrm{C}$ and $180^{\circ} \mathrm{C}$ for sweet sorghum and rice straw lignins respectively. All lignins exhibited low percentage of bio-char less than $10 \%$ remained unvalotilized at the end of the thermogravimetric analysis at $800^{\circ} \mathrm{C}$ in nitrogen atmosphere, revealing a high conversion yield into volatiles. Moreover, all lignin samples depicted higher cytotoxic potential towards lung cancer cell line (A549), $\mathrm{IC}_{50}: 12-17 \mu \mathrm{g} / \mathrm{ml}$. These findings suggest that the in-situ separated lignins would be good candidates for pyrolysis, polymer composites preparations and seem to be promising natural anti-cancer agents despite its main utilization as the caner drug delivery substrates.
\end{abstract}

\section{Keywords}

Lignocellulose, Lignin, Sweet Sorghum, Rice Straw, Sugarcane Bagasse, FTIR, SEM, TGA, Cytotoxicity 


\section{Introduction}

Dwindling fossil fuel resources as well as global climate change due to green house gas emission (GHG) [1] is a global concern nowadays and makes fuel based on the exploitation of biomass, an excellent alternative for both environment and development of bio-economy [2] [3] [4]. Lignocellulosic biomass ranges from forestry to agricultural residues are an abundant and a renewable resource on earth and can be converted into value-added products [5] by the main three steps, biomass pre-hydrolysis treatment, hydrolysis and fermentation.

Among the different lignocellulosic biomasses are rice straw, sweet sorghum and sugarcane bagasse comprises (25\% - 50\% cellulose, $15 \%-30 \%$ hemicelluloses and 15\% - 25\% lignin and minor other extractives) which are produced extensively in Egypt during grain and sweet sugar production as an agro-industrial waste, considered a potential for cellulose and lignin based industries [6]. These constituents could be used for the production of cellulose derivatives, plastics or could be used potentially as a substrate for the release of monomeric sugars essential for second-generation biofuel production, also they were used traditionally for a firewood, building materials, animal food, pulp industry and recently biosorbents [7].

Lignin is an underexploited side-stream low value material produced from paper industry and biorefineries. Its properties mainly depend on its native source and the isolation process.

Lignin is typically found in soft wood with a range of $25-35 \mathrm{wt} \%$ of dry matter, whereas the lignin content in hard wood is slightly lower 18 - $25 \mathrm{wt} \%$ [8], it is a highly present aromatic polymer on earth and the second frequently present organic polymer after cellulose and it is by far the most important source of aromatic compounds for the chemical industry [9] as well as pharmaceutical applications [10] [11] [12]. Out of the three main polymers in plant, lignin has the most complex, hydrophobic and heterogeneous in composition and structure. This tridimensional amorphous biopolymer is built up from phenyl propanoid (phenylpropane) units which are substituted at various positions, linked by ether and $\mathrm{C}-\mathrm{C}$ bonds. There are three basic building block structures abbreviated $\mathrm{H}$ (p-hydroxyphenyl), G (guaiacyl) and S (syringyl), differing in the number of methoxy groups on the aromatic ring; 0,1 or 2 , respectively. These structures can be represented in their alcohol form; namely as p-coumaryl, coniferyl, and sinapyl alcohols, Figure 1, these primary lignin building blocks originate from the shikimate pathway [13]. Lignin plays a key role in construction and strength to plant cell walls, changeable fluid movement to protect plant cell wall from microbial invasion [14].

Lignin is recognized as a highly branched amorphous biopolymer with a variety of functional groups including hydroxyl (aliphatic and aromatic), carboxylic, carbonyl and methoxyl groups [15] and can be classified into two main categories, Sulfur-free lignin and sulfur-containing lignin [16] according to the separation process. 


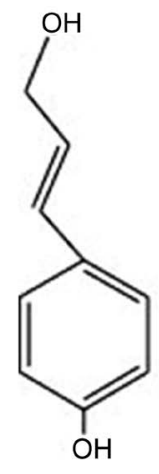

p-Coumaryl alcohol

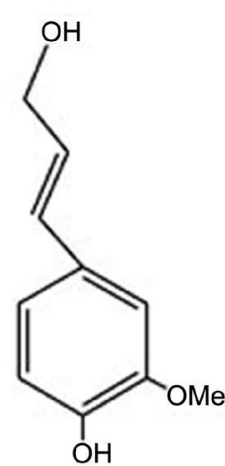

Coniferyl alcohol

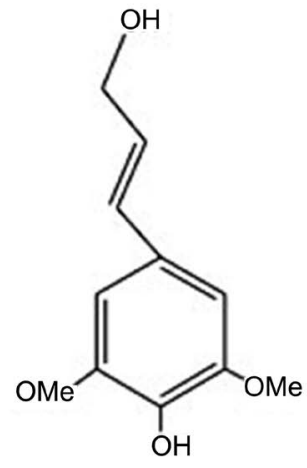

Sinapyl alcohol

Figure 1. The building blocks of lignin structure.

Currently there is a deep interest in biomass pretreatment technologies, which is the key factor in the second generation biorefinery commercialization and to obtain useful materials and products related to all biomass constituents enhance the economic viability of these lignocellulosic biorefinery [17] [18] [19] where lignin could be privileged into high-value added materials.

The lignin structure usually undergoes chemical modification during biomass pretreatment alter its native structure [20] and this drawbacks and restricts many of its potential industrial applications [20], therefore a successful biomass pretreatment technology must avoid both of lignin fragmentation, condensation reactions and demethoxylation.

One of the most common methods used to recover biomass lignin is steam explosion of fiber followed by a mild alkali extraction which is well known for fractionalizing lignocellulosic biomass into its main components [21] [22] [23], in addition to, there are four main technical lignins produced from pulping which are kraft lignin, soda lignin, lignosulfonate and organosolv lignin [24] relatively maintains its native structure.

The main objective of this study to follow up the morphological features change and thermal properties as well as cyto-toxicity of sweet sorghum, rice straw and sugarcane bagasse lignin recovered by a recently described in-situ sodium hydroxide-sodium bisulfate method using FTIR, SEM and thermal analyses to investigate its effect on the structural changes of these lignins which are categorized as a sulfur-free lignin that may evolve into industrial-scale value-added products [25] [26]. The in-situ process depends on treatment of lignocellulosic biomass using endothermic sodium hydroxide step followed by exothermic sodium bisulfate step generated in-situ in $42.2 \%$ yield. This method shows hemicelluloses solubilization $89 \%$, lignin removal $91 \%$, cellulose loss $5.8 \%$ and acellulosic substrate composition $87.6 \%$ cellulose, $4.9 \%$ hemicelluloses and $5.7 \%$ lignin as well as a negligible detection of furfural and 5-hydroxymethyl furfural [27] [28].

\section{Experimental}

\section{Materials and methods:}


Rice straw, sweet sorghum and sugarcane bagasse were provided from local Egyptian farmers in exception of the later provided from Abo-Korkas sugar mill factory, Elminia Governorate, Egypt. Chipped into small pieces $1 \mathrm{~cm}$ length and oven dried at $105^{\circ} \mathrm{C}$ for $48 \mathrm{~h}$. before conducting pretreatment experiments.

In situ sodium hydroxide-sodium bisulfate pretreatment:

The pretreatment was conducted using autoclave systec VE-75 using the described procedures. treatment of lignocellulosic biomass using sodium hydroxide $1.3 \%$ at $120^{\circ} \mathrm{C}$ for $40 \mathrm{~min}$. then treatment using sodium bisulfate generated in situ in an exo-thermic step, $42.2 \%$ yield, by adding equimolar amount of sulfuric acid to the slurry and keeping the temperature at $105^{\circ} \mathrm{C}$ for further $40 \mathrm{~min}$, total reducing sugar-containing hydrolyzate was determined using previously described procedures [29]. The resulting compressed wet substrate is then post-treated with $0.2 \%$ - $1 \%$ sodium hydroxide stirring on cold for lignin recovery and used for characterization without any further purification [27] [28].

Fourier Transform Infra-Red Analysis:

FTIR spectra were recorded on Nicolet 6700 spectrophotometer using potassium bromide.

\section{Scan electron microscopy:}

Lignin samples were dried and coated with gold and were imaged using scan electron microscopy, JOEL-JSM 5400 LV (Japan).

\section{Thermogravimetric Analysis:}

The study of the thermal properties was carried out by means of a thermogravimetric analysis (TGA) and first derivative of this curve (DTG), using a Shimadzu thermal analyzer DTG $80-\mathrm{H}$ (Japan). Scans were run from $30^{\circ} \mathrm{C}$ to $800^{\circ} \mathrm{C}$ with a heating rate of $10^{\circ} \mathrm{C} / \mathrm{min}$ under a flow of nitrogen of $40 \mathrm{ml} / \mathrm{min}$.

\section{Cytotoxic activity:}

Cytotoxic effect of the three lignin samples was tested on lung cancer cell line A549 by using (4,5-dimethylthiazol-2-yl)-2,5-diphenyltetrazolium bromide (MTT Assay). A549 lung cancer cells at a concentration of $10^{5}$ cells $/ \mathrm{ml}$ were inoculated into 96 well tissue culture plate ans incubation was maintained at $37^{\circ} \mathrm{C}$ under conditions of $5 \%$ and $95 \%$ of air for $24 \mathrm{~h}$ to develop a monolayer sheet before the treatment of the lignin compounds which after then were dissolved in DMSO and diluted in RPMI medium with $1 \%$ serum. Cells were treated with four different concentrations from each lignin sample for the next $24 \mathrm{~h}$. MTT solution was prepared at concentration of $5 \mathrm{mg} / \mathrm{ml}$ and then $20 \mu \mathrm{l}$ MTT solution was added to each well and incubated the plate for $4-5 \mathrm{~h}$. $200 \mu \mathrm{L}$ DSO was used to dissolve the insoluble formazan and the purple optical density was measured at $570 \mathrm{~nm}$ which is directly proportional to the cell viability [30].

\section{Results and Discussion}

For lignin composition, lignin samples were characterised by means of the determination of its content in Klason lignin and ashes. Ash content was determined gravimetrically, after combustion of the sample at $800^{\circ} \mathrm{C} \pm 25^{\circ} \mathrm{C}$ for 3 
hours in a muffle furnace [31]. Klason lignin content was also determined gravimetrically after acid hydrolysis of the sample [32], for sugar analysis, Aliquots of $3 \mathrm{ml}$ of $72 \% \mathrm{H}_{2} \mathrm{SO}_{4}$ were added to $1 \mathrm{~g}$ samples of lignin in pressure tubes. The tubes were placed in a water bath at $30^{\circ} \mathrm{C}$ for $1 \mathrm{~h}$ and stirred intermittently to completely wet the lignin sample. The solution was then diluted to $50 \mathrm{ml}$ through the addition of water and the samples were autoclaved in pressure tubes at $121^{\circ} \mathrm{C}$ for $1 \mathrm{~h}$. The samples were further diluted to $100 \mathrm{ml}$, filtered with porcelain crucibles to remove solids and the liquid fraction was neutralized using sodium bicarbonate and analyzed for total reducing sugar using the mentioned procedures [29], Table 1.

FT-IR Analysis:

The effects caused by the different lignin polymeric structures in the FTIR spectra are presented. The recorded spectra of lignin samples were compared with its assignments.

All lignins showed a strong wide band within the range 3400 and $3100 \mathrm{~cm}^{-1}$, assigned to the hydroxyl groups in both of phenolic and aliphatic structures. The two bands located at 2919 and $2850 \mathrm{~cm}^{-1}$, due to the symmetrical and asymmetrical $\mathrm{CH}$ stretching of the methyl and methylene groups are also noticed in the three samples.

The absorption band of $1649 \mathrm{~cm}^{-1}$ was identified in all three lignin samples is assigned to the stretching vibrations of conjugated carbonyl groups, there are some bands which are present in all the studied lignin fractions, such as bands located at 1595 and $1510 \mathrm{~cm}^{-1}$, related to vibrations of aromatic rings, and two other bands attributed to methoxyl groups present at 1455 and $1424 \mathrm{~cm}^{-1}$.

\section{Thermal analysis:}

The thermogravimetric (TG) analysis indicates weight loss of lignin samples in relation to the temperature of degradation, and the first derivative of that curve (DTG) which shows the corresponding rate of weight loss for every one of the obtained samples, respectively. The peak of this curve $\left(\mathrm{DTG}_{\max }\right)$ may be expressed as the temperature of maximal degradation rate.

Sugarcane bagasse lignin, Figure 2, showed the highest value of $\mathrm{DTG}_{\max }$ $\left(494.76^{\circ} \mathrm{C}\right)$, and its thermal stability around $201^{\circ} \mathrm{C}$ while for sweet sorghum and rice straw lignins, Figure 3 and Figure 4 respectively, the obtained values of $\mathrm{DTG}_{\max }$ were $450.66^{\circ} \mathrm{C}$ and $464.33^{\circ} \mathrm{C}$, and their thermal stabilities around $173^{\circ} \mathrm{C}$ and $180^{\circ} \mathrm{C}$ respectively. Thus, sugarcane bagasse lignin is the most thermally stable sample of this study and also as compared to sugarcane bagasse lignin isolated

Table 1. Klason, ash and total sugar content in lignin samples separated by in-situ method.

\begin{tabular}{cccc}
\hline & Klason lignin\% & Ash\% & Total reducing sugars\% \\
\hline Sweet sorghum lignin & $92.41 \pm 0.55$ & $0.98 \pm 0.08$ & $4.14 \pm 0.13$ \\
Rice straw lignin & $91.89 \pm 0.49$ & $1.12 \pm 0.08$ & $4.14 \pm 0.16$ \\
Sugarcane bagasse lignin & $90.87 \pm 0.61$ & $0.96 \pm 0.09$ & $5.06 \pm 0.15$
\end{tabular}




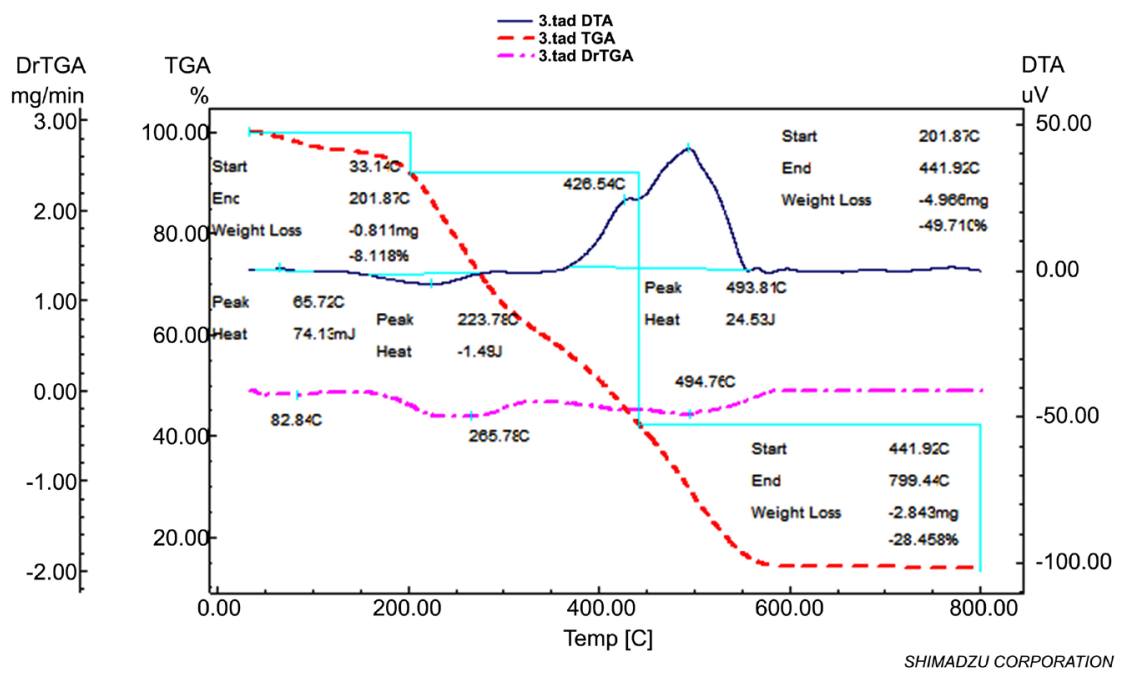

Figure 2. Thermal analysis of sugarcane bagasse lignin.

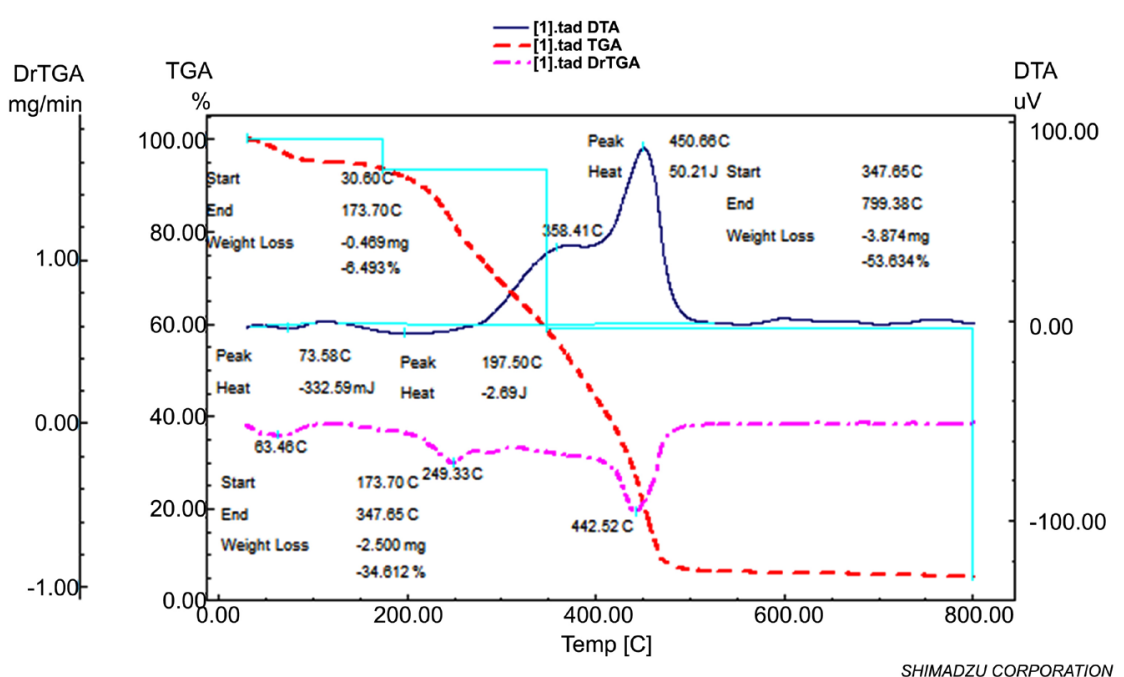

Figure 3. Thermal analysis of sweet sorghum lignin.

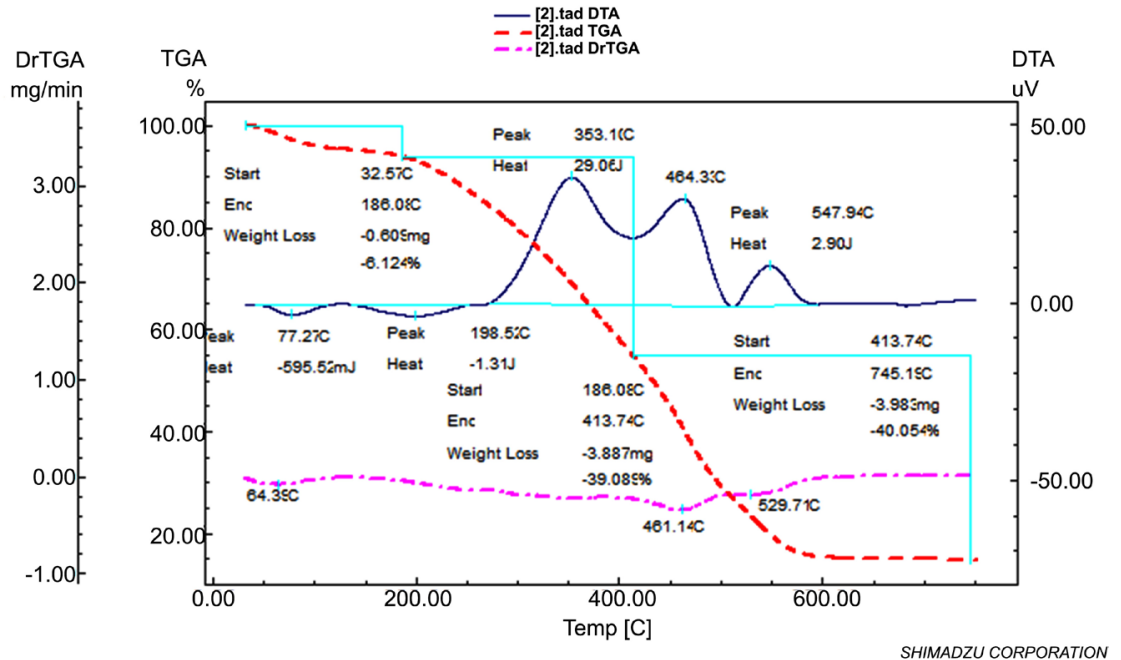

Figure 4. Thermal analysis of rice straw lignin. 
by the soda process which is thermally stable around $175^{\circ} \mathrm{C}$ and its maximal degradation temperature was $380^{\circ} \mathrm{C}$ [33], and also as compared to kraft sugarcane lignin which is thermally stable below $190^{\circ} \mathrm{C}$ and its maximal degradation temperature was $377^{\circ} \mathrm{C}$ [34].

At the end of the thermogravimetric analysis $\left(800^{\circ} \mathrm{C}\right.$, in a nitrogen atmosphere) a very low percentage of residues remain unvolatilized, bio-char and/or highly condensed aromatic compound is obtained, in contrary to many literature [35] regarding thermal degradation of different lignin resources, also disagrees to both of soda sugarcane bagasse lignin [33] and sugarcane bagasse kraft lignin [34] that gives a high percentage of these unvalotalized residues at the end of thermogravimetric analysis strongly indicates the in-situ separated lignins are higher in methoxy content [36] giving a very low unvalotilized residues and consequently a good candidate for pyrolysis.

Degradation of the lignin samples can be divided into three stages [37] [38]. In stage one, the initial weight loss step occurred at $30^{\circ} \mathrm{C}-120^{\circ} \mathrm{C}$ due to the evaporation of water absorbed. Stage two is seen to take place around $180^{\circ} \mathrm{C}$ $350^{\circ} \mathrm{C}$ and is attributed to the degradation of components of carbohydrates in the lignin samples, which are converted to volatile gases such as $\mathrm{CO}, \mathrm{CO}_{2}$, and $\mathrm{CH}_{4}$. The final stage of degradation occurred over a wide range of temperatures above $350^{\circ} \mathrm{C}$. Within this stage, degraded volatile products derived from lignin including phenolics, alcohols, aldehyde and acids along with the formation of gaseous products are getting removed.

Scan Electron Microscopy, SEM micrograms: (Figures 5-7)
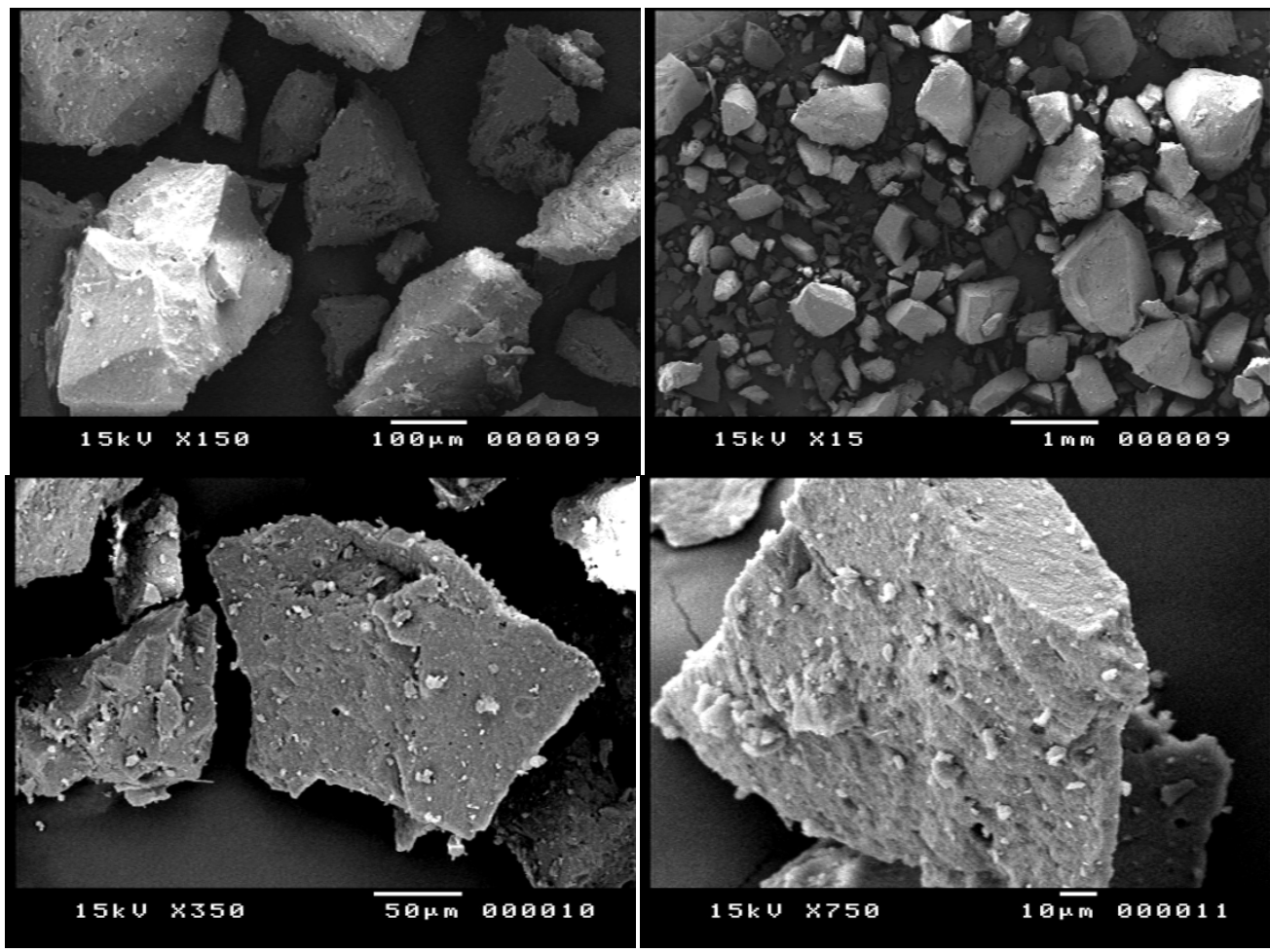

Figure 5. SEM micrographs of in-situ sugarcane bagasse lignin. 

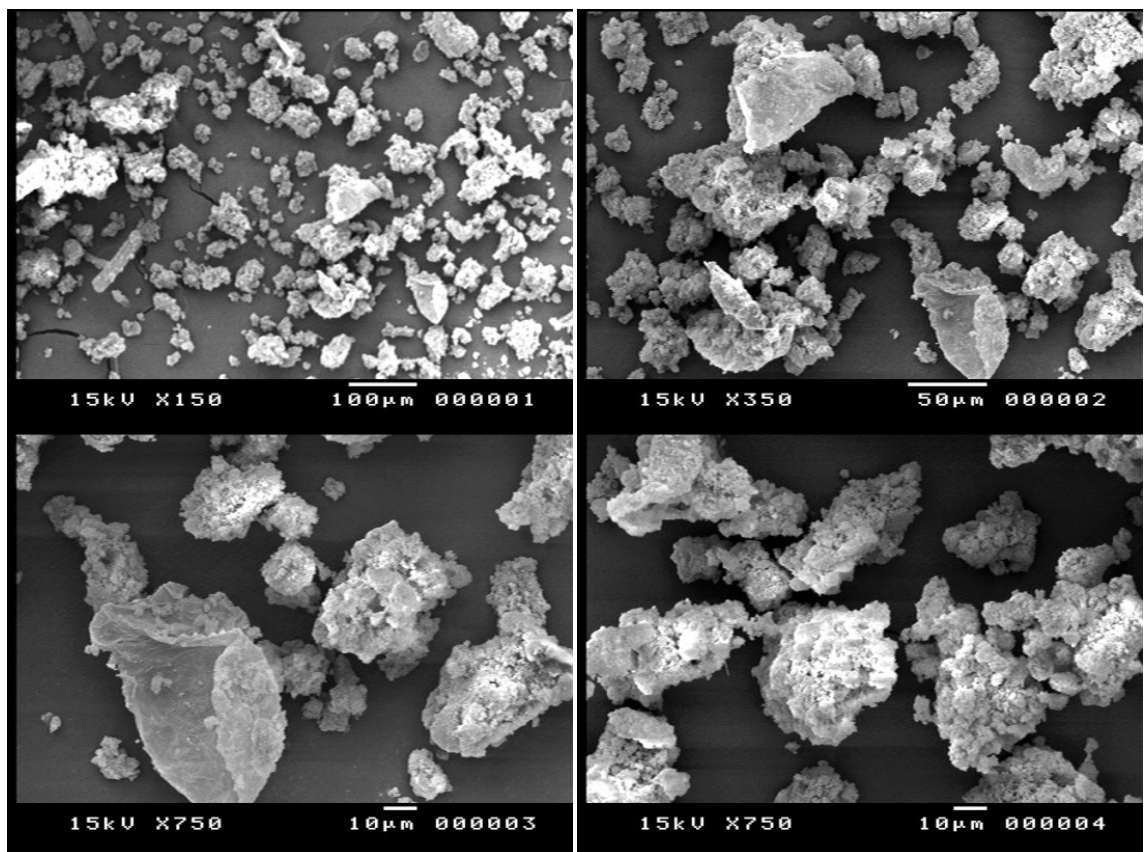

Figure 6. SEM micrographs of in-situ sweet sorghum lignin.
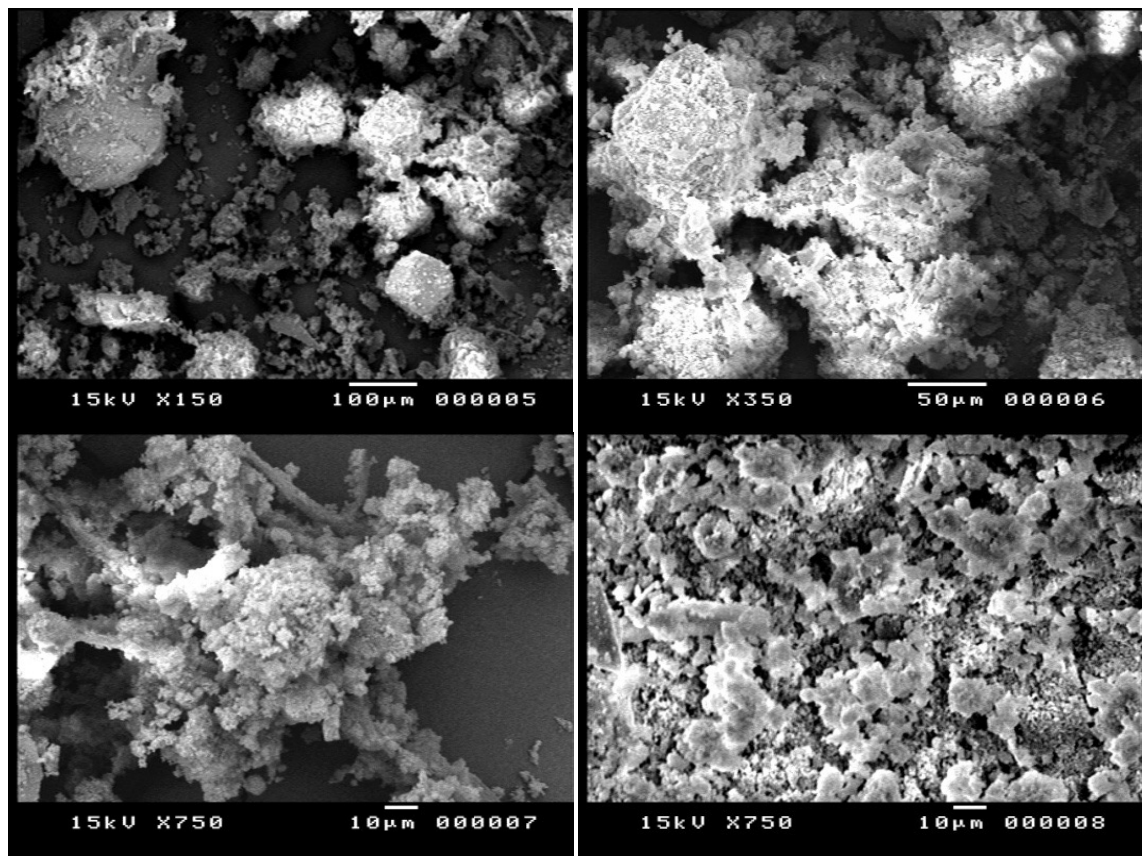

Figure 7. SEM micrographs of in-situ rice straw lignin.

The scan electron microscope morphologies of both of sweet sorghum and rice straw lignin reveal sponge-like structures with a high degree of agglomeration in case of rice straw lignin, in contrary to sugarcane bagasse lignin which obviously appears as rock-like structure with different particle size and relatively porous surface.

Cytotoxicity activity:

All the three lignin samples separated by the in-situ method had a remarkable 


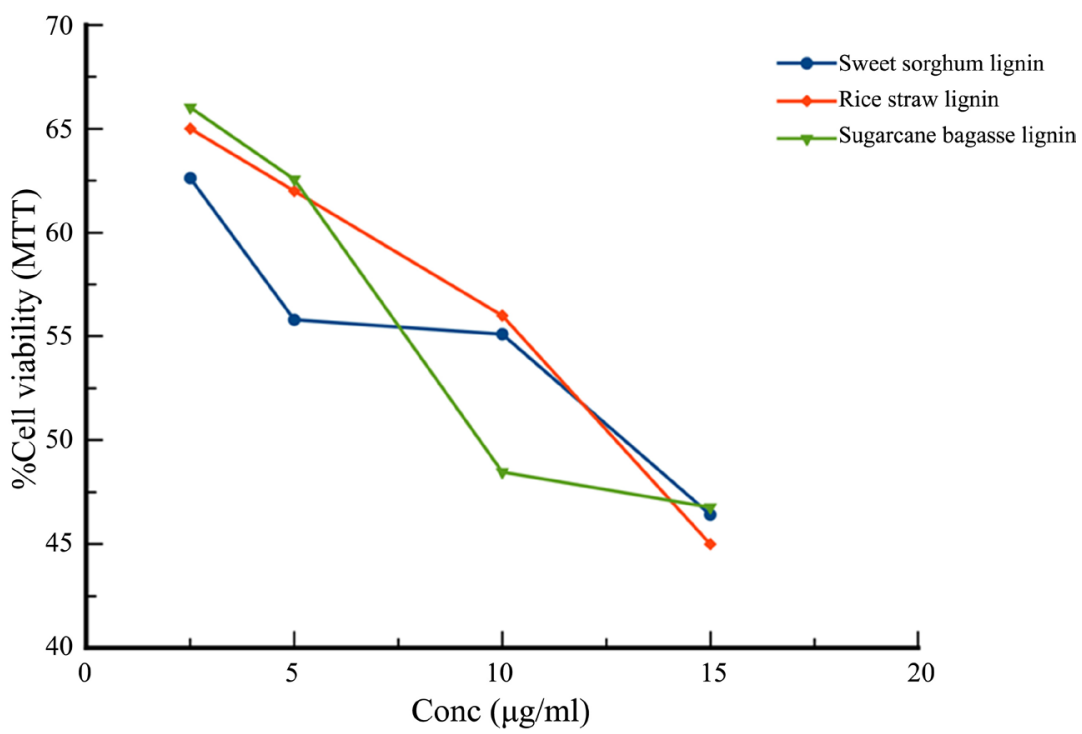

Figure 8. Cytotoxic effect of sweet sorghum, rice straw and sugarcane bagasse lignin towards lung cancer cell line A549, at different concentrations and conducted in triplicate.

Table 2. The corresponding $\mathrm{IC}_{50}$ value for each lignin.

\begin{tabular}{cc}
\hline Compound & IC $_{50} \mu \mathrm{g} / \mathrm{ml}$ \\
\hline Sweet sorghum lignin & 12.5 \\
Rice straw lignin & 17.9 \\
Sugarcane bagasse lignin & 12.2 \\
\hline
\end{tabular}

cytotoxic effect towards lung cancer cell line A549 giving $\mathrm{IC}_{50}$ value, a concentration of a sample that is required for $50 \%$ inhibition in-vitro, ranges $12-18$ $\mu \mathrm{g} / \mathrm{ml}$ suggest the potential of the three lignin samples as a natural anti-cancer agents and the results show sugarcane bagasse lignin is the most promising despite the fact it gas well been used as a cancer drugs delivery substrates due to its non toxicity and good physiochemical compatibility as well as bio-degradable properties (Figure $8 \&$ Table 2).

\section{Conclusion}

Three types of lignocellulosic biomass lignin samples were isolated using in-situ sodium hydroxide-sodium bisulfate method and characterization was performed using fourier transform infrared spectroscopy, thermogravimetric analysis and Scan electron microscopy as well as cytotoxicity effect was examined. The results reveal the in-situ lignin samples were thermally stable in addition to low bio-char formation at high temperatures under nitrogen atmosphere indicated its suitability in polymer composites preparation and good candidates for pyrolysis and the cytotoxicity results suggest these lignin samples would be a natural anti-cancer lead.

\section{Conflicts of Interest}

The authors declare no conflicts of interest regarding the publication of this paper. 


\section{References}

[1] Asumado, S. and Asantewaa, P. (2016) Feasibility of Biomass Heating System in Middle East Technical University, Northern Cyprus Campus. Cogent Engineering, 3, Article ID: 1134304. https://doi.org/10.1080/23311916.2015.1134304

[2] Abbasi, T., Premalatha, M. and Abbasi, S. (2011) The Return to Renewables: Will It Help in Global Warming Control? Renewable and Sustainable Energy Reviews, 15, 891-894. https://doi.org/10.1016/j.rser.2010.09.048

[3] Kaygusuz, K. (2012) Energy for Sustainable Development: A Case of Developing Countries. Renewable and Sustainable Energy Reviews, 16, 1116-1126. https://doi.org/10.1016/i.rser.2011.11.013

[4] Clauser, N.M., Gutiérrez, S., Area, M.C., Felissia, F.E. and Vallejos, M.E. (2016) Small-Sized Biorefineries as Strategy to Add Value to Sugarcane Bagasse. Chemical Engineering Research and Design, 107, 137-146. https://doi.org/10.1016/j.cherd.2015.10.050

[5] Cheng, S.M. and Zhu, S.D. (2008) Use of Lignocellulosic Materials for a Sustanaibale Chemical Industry. Bioresources, 3, 666-667.

[6] Asada, C., Nakamura, Y. and Kobayashi, F. (2005) Waste Reduction System for Production of Useful Materials from Un-Utilized Bamboo Using Steam Explosion Followed by Various Conversion Methods. Biochemical Engineering Journal, 23, 131-137. https://doi.org/10.1016/j.bej.2004.11.004

[7] Said, A.E.-A.A., Ali, A.A.M., Goda, M.N., El-Al, M.A. and Abdelazim, M. (2018) Modified Sugarcane Bagasse with Tartaric Acid for Removal of Diazonium Blue from Aqueous Solutions. Journal of Polymers and the Environment, 26, 2424-2433. https://doi.org/10.1007/s10924-017-1136-9

[8] Mutturi, S., Palmqvist, B. and Liden, G. (2014) Developments in Bioethanol Fuel-Focused Biorefineries. In: Waldron, K., Ed., Advances in Biorefineries. Biomass and Waste Supply Chain Exploitation, Woodhead Publishing, Sawston, 259-302. https://doi.org/10.1533/9780857097385.1.259

[9] Laurichesse, S. and Avérous, L. (2014) Chemical Modification of Lignins: Towards Biobased Polymers. Progress in Polymer Science, 39, 1266-1290.

https://doi.org/10.1016/j.progpolymsci.2013.11.004

[10] Liu, X.H., Wang, J.F., Li, S.H., Zhuang, X.W., Xu, Y.Z., Wang, C.P. and Chu, F.X. (2014) Preparation and Properties of UV-Absorbent Lignin Graft Copolymer Films from Lignocellulosic Butanol Residue. Industrial Crops and Products, 52, 633-641. https://doi.org/10.1016/j.indcrop.2013.11.036

[11] Lu, Q., Zhu, M.H., Zu, Y.G., Liu, W.J., Yang, L., Zhang, Y., Zhao, X.H., Zhang, X.N. and Li, W.G. (2012) Comparative Antioxidant Activity of Nanoscale Lignin Prepared by a Supercritical Antisolvent (SAS) Process with Non-Nanoscale Lignin. Food Chemistry, 135, 63-67. https://doi.org/10.1016/j.foodchem.2012.04.070

[12] Vinardell, P., Ugartondo, V. and Mitjans, M. (2008) Potential Applications of Antioxidant Lignins from Different Sources. Industrial Crops and Products, 27, 220-223. https://doi.org/10.1016/j.indcrop.2007.07.011

[13] Higuchi, T. (1990) Lignin Biochemistry: Biosynthesis and Biodegradation. Wood Science and Technology, 24, 23-63. https://doi.org/10.1007/BF00225306

[14] Boerjan, W., Ralph, J. and Baucher, M. (2003) Lignin Biosynthesis. Annual Review of Plant Biology, 54, 519-546. https://doi.org/10.1146/annurev.arplant.54.031902.134938

[15] Alder, E. (1977) Lignin Chemistry-Past, Present and Future. Wood Science and 
Technology, 11, 169-218. https://doi.org/10.1007/BF00365615

[16] Lora, J.H. and Glasser, W.G. (2002) Recent Industrial Applications of Lignin: A Sustainable Alternative to Nonrenewable Materials. Journal of Polymers and the Environment, 10, 39-48. https://doi.org/10.1023/A:1021070006895

[17] Valdivia, M., Galan, J.L., Laffarga, J. and Ramos, J. (2016) Biofuels 2020: Biorefineries Based on Lignocellulosic Materials. Microbial Biotechnology, 9, 585-594. https://doi.org/10.1111/1751-7915.12387

[18] Naik, S.N., Goud, V.V., Rout, P.K. and Dalai, A.K. (2010) Produntion of First and Second Generation Biofuels: A Comprehensive Review. Renewable and Sustainable Energy Reviews, 14, 578-597. https://doi.org/10.1016/j.rser.2009.10.003

[19] Demirbas, A. (2009) Biofuels Securing the Plant's Future Energy Needs. Energy Conversion and Management, 50, 2239-2249. https://doi.org/10.1016/j.enconman.2009.05.010

[20] Constant, S., Wienk, H.L.J., Frissen, A.E., De Peinder, P., Boelens, R., Van Es, D.S., Grisel, R.H.J., Weckhuysen, B.M., Huijen, W.J.J. and Gosselink, R.J.A. (2016) New Insights into the Structure and Composition of Technical Lignins: A Comparative Characterization Study. Green Chemistry, 18, 2651-2665.

https://doi.org/10.1039/C5GC03043A

[21] Ibrahim, M., Agblevor, F. and El-Zawawy, W. (2010) Isolation and Characterization of Cellulose and Lignin from Steam-Exploded Lignocellulosic Biomass. Bioresources, 5, 397-418.

[22] Delong, A. (1981) Method of Rendering Lignin Separable from Cellulose and Lignocelluloses in Lignocellulosic Material and the Product So Produced. Canada Patent No. 1096374.

[23] Neguyen, A. (1989) Continuous Leaching of Lignin or Hemicelluloses and Lignin from Steam Pre-Treatment Lignocellulosic Particulate Material. Canada Patent No. 1323366.

[24] Josefsson, T., Lennholm, H. and Gellerstedt, G. (2002) Steam Explosion of Aspen Wood, Characterization of Reaction Products. Holzforschung, 56, 289-297.

https://doi.org/10.1515/HF.2002.047

[25] Kohnke, J., Gierlinger, N., Prats-Mateu, B., Unterweger, C., Solt, P., Mahler, A., Schwaiger, E., Liebner, F. and Gindl-Altmutter, W. (2019) Comparison of Four Technical Lignins as a Resource for Electrically Conductive Carbon Particles. BioResources, 14, 1091-1109.

[26] Gosselink, A., De Jong, E., Guran, B. and Abacherli, A. (2004) Co-Ordination Network for Lignin-Standardization, Production and Applications Adapted to Market Requirements. Industrial Crops and Products, 20, 121-129.

https://doi.org/10.1016/j.indcrop.2004.04.015

[27] Zohri, A., Abdelwahab, M., Ali, M., Ibrahim, S. and Abdelazim, M. In-Situ Sodium Hydroxide-Sodium Bisulfate Sugarcane Bagasse Pretreatment for Biofuel Production. Egypt Patent Office. Application No. 1349/2017.

[28] Zohri, A., Abdelwahab, M., Ali, M., Ibrahim, S. and Abdelazim, M. (2019) Data On Morphological Features Change of Pre-Hydrolysis Treated Sugarcane Bagasse Using in Situ Sodium Hydroxide-Sodium Bisulfate Method. Data in Brief, 24, Article ID: 103971. https://doi.org/10.1016/j.dib.2019.103971

[29] Zohri, A.-N., Abdelazim, M. and Ibrahim, S. (2018) 2-Aminoethanaminium 2-(Ethoxycarbonyl)-4,6-Dinitrophenolate as a Greener Route in Reducing Sugar Quantification. Methodsx, 5, 609-612. https://doi.org/10.1016/j.mex.2018.05.017 
[30] Mosmann, T. (1983) Rapid Colorimetric Assay for Cellular Growth and Survival. Application to Proliferation and Cytotoxicity Assays. Journal of Immunological Methods, 65, 55-63. https://doi.org/10.1016/0022-1759(83)90303-4

[31] Abacherli, A. (2008) Determination of Ash Content in Lignin by Combustion (Ili003). Analytical Methods for Lignin Characterization. International Lignin Institute, Lausanne.

[32] Robles, J., Espinosa, E., Savy, D., Rosal, A. and Rodriguez, A. (2016) Biorefinery Process Combining Specel Process and Selective Lignin Precipitation Using Mineral Acids. BioResources, 11, 7061-7077. https://doi.org/10.15376/biores.11.3.7061-7077

[33] Mousavioun, P. and Doherty, W. (2010) Chemical and Thermal Properties of Fractionated Bagasse Soda Lignin. Industrial Crops and Products, 31, 52-58.

https://doi.org/10.1016/j.indcrop.2009.09.001

[34] Jia, Z., Li, M.F., Wan, G.C., Luo, B., Guo, C.Y., Wang, S.L. and Min, D.Y. (2018) Improving the Homogeneity of Sugarcane Bagasse Kraft Lignin through Sequential Solvents. RSC Advances, 74, 42269-42279. https://doi.org/10.1039/C8RA08595A

[35] Brebu, M. and Vasile, C. (2010) Thermal Degradation of Lignin-A Review. Cellulose Chemistry and Technology, 44, 353-363.

[36] Scholze, B., Hanser, C. and Meier, D. (2001) Journal of Analytical and Applied Pyrolysis, 60,41

[37] Tegado, A., Pena, C., Labidi, J., Echeverria, J.M. and Mondragon, I. (2007) Physico-Chemical Characterization of Lignins from Different Sources for Use in Phenol-Formaldehyde Resin Synthesis. Bioresource Technology, 98, 1655-1663. https://doi.org/10.1016/j.biortech.2006.05.042

[38] Watkins, D., Nuruddin, M., Hosur, M., Techerbi-Narteh, A. and Jeelani, S. (2015) Extraction and Characterization of Lignin from Different Biomass Resources. Journal of Materials Research and Technology, 4, 26-32.

https://doi.org/10.1016/j.jmrt.2014.10.009 